\title{
Cultivating junior high school students' critical thinking skills by using short-videos in english language classroom
}

\author{
Merjen Atayeva ${ }^{1, *}$ \\ ${ }_{1}^{1}$ Yogyakarta State University, Yogyakarta, Indonesia \\ 1 merjenata88@gmail.com \\ * corresponding author
}

\section{ARTICLE INFO}

Article history

Received : April 10, 2019

Revised : May 7, 2019

Accepted : May 28, 2019

\section{Keywords}

Critical thinking

Shorts video

Junior high school

\begin{abstract}
An effective teaching method for cultivating students' critical thinking skills of junior high school students in Indonesia is very necessary as their critical thinking ability is still low. This research is a descriptive study which aimed at cultivating learners' critical thinking by using short-videos since it is believed that technology can motivate the students, increase their interest, engage them to the lesson matter, provide effective learning activities, and demand them to think critically and creatively. The subject in this study were 130 Junior High School students (SMP Negeri 1 Sedayu, Yogyakarta) grade IX. The students were homogeny in term of age, economic, and social background as well as in English language score. Facione's critical thinking rubrics were used to indicate the level of students' critical thinking such as their interpretation, analysis, evaluation, inference, explanation, and selfregulation skill of short video. The average score of all item in pre-test critical thinking skills was at fair level with the score 9 out of 20. The results indicate the students' interpretation skills were fair with the score of 9 out of 20; analytical skill was 12; evaluation skill was 9 out of 20; self-regulation was in fair criterion with the score of 5 out of 10 and good level of explanatory's skill with the score 6 out of 10 , while 12 for inferences. It can be concluded that the critical thinking skill of the students of Junior High School was still unsatisfactory as most of them can only reach fair levels. The use of video cannot improve all critical thinking skills. It is recommended more practices for the students.
\end{abstract}

This is an open access article under the CC-BY-SA license.

\section{Introduction}

The need for obtaining an effective teaching method for cultivating students' critical thinking skills of junior high school students in Indonesia is paramount because their critical thinking ability is still low. It is revealed from research done by the Program for International Student Assessment (PISA) 2015 that Indonesia science literacy score is 403, which is lower than OECD (493). The average performance in the reading of 15-year-olds is shown 397, compared to an average of score OECD 493 (PISA, 2015). It reflects that Indonesian students' skill in answering the questions refer to critical, logical, and problem-solving skills are still insufficient. Students needed to be trained during the learning process. 
Kamali \& Fahim (2011:2), mentioned,

...critical thinking is the skill to look over, against with own perspectives, and promote ideas; to argue inductively and deductively, and to reach factual or judgmental conclusions based on firm inferences drawn from clear statements of knowledge or belief.

There are some factors that affecting critical thinking of Indonesian students: the language proficiency, assessment methods, motivation, support at home, prior linguistic knowledge, learning environment, teaching strategies, comprehensible input, student personality, age, comfort in their country of residence, etc (Indah, 2016).

Several studies have been conducted to foster the Indonesian students' critical thinking (Elisanti, 2017; Haridz and Irving, 2017; Saputri, Sajidan, and Rinanto, 2018) but the results are still unsatisfactory as the students critical thinking were at the average level. The results of previous research have not achieved the Indonesian National Education Standards Agency (BSNP) standard that must be met in the 21st-century education process in which the students should have changed factual thinking style to the critical, and from the delivery of knowledge to the exchange of knowledge (BSNP, 2010)

The idea of combining critical thinking into education was developed by Greek philosophers after World War II and strengthen by Bloom in the 1950s with his Taxonomy of Educational Objectives. The idea was gladly accepted in the 1980s. It has held the probe of time and yet there is still a deliberate need for strengthening the critical thinking skills in schools and colleges (Djiwandono, 2013). It is effortless and common by the teachers to transfer the knowledge from textbooks to the students, nevertheless, to make learners think more independently and learn from themselves beside textbooks is a great challenge/effort (Djiwandono, 2013). Combine critical thinking into education could help learners to deal with social and environmental issues (Djiwandono, 2013).

Critical" is from the Greek word "krisis", which means "to separate". Without critical thinking one might not be able to separate himself from the crisis which sucks into the damage, even he or she might block his or her pathways to success. Non-traditional thinking, grounded in traditional, logical idea, allows us to determine exactly what the crisis is and how to move out of it (Caroselli, 2009). Paul (1995) says, "Critical thinking is thinking about your thinking while you are thinking in order to make your thinking better".

According to Fahim (2010), critical thinking is learning how to ask and answer questions of analysis, synthesis, and evaluation. In detail, Facione (2015) defined the core critical thinking skills into two categories, cognitive and disposition skills.

Cognitive skills are meant being in the very core of critical thinking. It involves six skills namely: interpretation, analysis, evaluation, inference, explanation, and self-regulation. Facione (2015) explains, interpretation is to comprehend and express the meaning or significance of a wide variety of "experiences, situations, data, events, judgments, conventions, beliefs, rules, procedures, or criteria" (p: 15). The categorization, decoding significance, and clarifying meaning is considered the sub-skills of interpretation (Facione, 2015). The analysis is considered as an ability to identify the intended and real inferential relationships between statements, questions, concepts, descriptions, or other forms of representation. The experts infer examining ideas, detecting arguments, and analyzing arguments as sub-skills of analysis (Facione, 2015). The evaluation is judging about the arguments whether it is reliable and rational based on the logic and evidence given. The inference is the ability to identify, to decide what to believe, to draw reasonable conclusions based on strong logic, to form assumptions and hypotheses and to grasp relevant information or consequences of this decision. The experts involve querying evidence, conjecturing alternatives, and drawing conclusions as sub-skills of inference (Facione, 2015). The explanation is the ability to communicate and present in a cogent and coherent way. The sub-skills under clarification are describing methods and outcome, giving a reason on procedures, proposing and stand up for with good reasons one's factual and theoretical explanations of events or points of view, and come with full and well-reasoned, arguments in the context of findings the best comprehension possible (Facione, 2015). The selfregulation is one's the ability to monitor his or her own thinking, being conscious in cognitive 
activities. Two sub-skills were defined by experts in self-regulation: self-examination and selfcorrection. Which means one has the ability to monitor and correct flaws in logic (Facione, 2015).

The disposition is,

... the ideal critical thinker who is habitually curious, well-literate, trustful of reason, openminded, flexible, fair-minded in evaluation, honest in facing personal biases, prudent in making judgments, willing to reconsider, clear about issues, orderly in complex matters, diligent in seeking relevant information, reasonable in the selection of criteria, focused in inquiry, and persistent in seeking results which are as precise as the subject and the circumstances of inquiry permit (Facione, 2015:15).

The ability to think critically, however, will not ensure unless one has a strong intention and initiative to combine in the process relevant to it. In addition, besides the ability to enhance in cognitive skills, good critical thinkers needed to have strong intention to identify the significance of good thinking and have the creativity to seek better judgment (Shirkhani \& Fahim, 2011).

Engaging critical thinking into the language learning process or activities is considered as one of the language teachers' innovation because the students will expand their learning experience and will learn the language meaningfully. The learners' good performance indicates that they have good critical thinking skills (Pinter, 2017). Some studies have confirmed that critical thinking skills improve ESL writing ability language proficiency, oral communication ability, etc (Alharbi, 2015; Hawks, Turner, Derouin, Hueckel, Leonardelli, \& Oermann, 2016; Indah, 2013; Samanhudi, \& Sampurna, 2010; and Shirkhani \& Fahim, 2011).

Language skills cannot be separated from cognitive or critical thinking. Teaching critical thinking skills includes transferring the facts or information or concepts (Krathwohl, \& Anderson, 2009). Critical thinking is focused on deciding what to believe or to do (Norris \& Ennis, 1996).

Language learners who have critical thinking skills are more creative and capable than those who haven't to achieve the goals of the curriculum. Shirkhani \& Fahim (2011:3) mentions,

Learners with critical thinking skills are capable of thinking critically and creatively; capable of making decisions and solving problems; capable of using their thinking skills, and of understanding language or its contents; capable of treating thinking skills as lifelong learning; and finally they are intellectually, physically, emotionally and spiritually well-balanced.

This research was done to foster students' critical thinking skills through the use of short-videos since it is believed that technology can motivate the students; increase their interest; engage them to the lesson matter; provide them with effective learning activities; and involve them to think critically and creatively (Carvajal, \& Paulina, 2019; Ding, Ottenbreit-Leftwich, \& Glazewski, 2019; Gurbangeldiyewna, 2016; McQuiggan, McQuiggan, Sabourin, \& Kosturko, 2015; Ohler, 2013; and Sulla, Bosco, \& Marks, 2019).

An effective teaching method for cultivating students' critical thinking skills of junior high school students in Indonesia is very necessary as their critical thinking ability is still low. This research is a descriptive study which aimed at cultivating learners' critical thinking by using short-videos since it is believed that technology can motivate the students, increase their interest, engage them to the lesson matter, provide effective learning activities, and demand them to think critically and creatively. The subject in this study were 130 Junior High School students (SMP Negeri 1 Sedayu, Yogyakarta) grade IX. The students were homogeny in term of age, economic, and social background as well as in English language score. Facione's critical thinking rubrics were used to indicate the level of students' critical thinking such as their interpretation, analysis, evaluation, inference, explanation, and self-regulation skill of short video. The average score of all item in pretest critical thinking skills was at fair level with the score 9 out of 20 . The results indicate the students' interpretation skills were fair with the score of 9 out of 20; analytical skill was 12; evaluation skill was 9 out of 20; self-regulation was in fair criterion with the score of 5 out of 10 and good level of explanatory's skill with the score 6 out of 10, while 12 for inferences. It can be concluded that the critical thinking skill of the students of Junior High School was still unsatisfactory as most of them can only reach fair levels. The use of video cannot improve all critical thinking skills. It is recommended more practices for the students. 


\section{Method}

This is descriptive research using the instruments which developed based on the rubrics of critical thinking skills developed by Facione (2015). The subjects in this study were 130 students in grade 9 (5 classes) of Junior High School students (SMP Negeri 1 Sedayu, Yogyakarta) selected through purposive sampling technique. The data were obtained from the analysis of student answers. After coding each student's answers and scoring them, then they were categorized into several score levels excellent, good, average, fair, poor, or very poor in term of students' interpretation, analysis, evaluation, inference, explanation, and self-regulation skills. Facione's critical thinking rubrics were used to determine the level of students' critical thinking as seen in table 1 and 2 below;

Table 1. Rubric for rating the critical thinking (Facione, 2015. p: 9)

\begin{tabular}{|c|c|c|c|}
\hline Skill/category & $\begin{array}{c}\text { Core critical thinking skills } \\
\text { Experts' Consensus Description }\end{array}$ & Subskill/elements & Score \\
\hline Interpretation & $\begin{array}{l}\text { "To comprehend and express the } \\
\text { meaning or significance of a wide } \\
\text { variety of experiences, situations, } \\
\text { data, events, judgments, conventions, } \\
\text { beliefs, rules, procedures, or criteria" }\end{array}$ & $\begin{array}{l}\text { Categorize } \\
\text { Decode } \\
\text { significance } \\
\text { Clarify } \\
\text { meaning }\end{array}$ & $\begin{array}{l}\text { Excellent- } 18-20 \\
\text { Good - 13-17 } \\
\text { Average - } 10-12 \\
\text { Fair - 7-9 } \\
\text { Poor-5-6 } \\
\text { Very poor- } 0-5\end{array}$ \\
\hline Analysis & $\begin{array}{l}\text { "To identify the intended and actual } \\
\text { inferential relationships among } \\
\text { statements, questions, concepts, } \\
\text { descriptions, or other forms of } \\
\text { representation intended to express } \\
\text { belief, judgment, experiences, } \\
\text { reasons, information, or opinions" }\end{array}$ & $\begin{array}{l}\text { Examine ideas } \\
\text { Identify } \\
\text { arguments } \\
\text { Identify } \\
\text { reasons and } \\
\text { claims }\end{array}$ & $\begin{array}{l}\text { Excellent- } 18-20 \\
\text { Good - } 13-17 \\
\text { Average - } 10-12 \\
\text { Fair - 7-9 } \\
\text { Poor- 5-6 } \\
\text { Very poor- } 0-5\end{array}$ \\
\hline Inference & $\begin{array}{l}\text { "To identify and secure elements } \\
\text { needed to draw reasonable } \\
\text { conclusions; to form conjectures and } \\
\text { hypotheses; to consider relevant } \\
\text { information and to reduce the } \\
\text { consequences flowing from data, } \\
\text { statements, principles, evidence, } \\
\text { judgments, beliefs, opinions, } \\
\text { concepts, descriptions, questions, or } \\
\text { other forms of representation" }\end{array}$ & $\begin{array}{l}\text { Query } \\
\text { evidence } \\
\text { Conjecture } \\
\text { alternatives } \\
\text { Draw logically } \\
\text { valid or } \\
\text { justified } \\
\text { conclusions }\end{array}$ & $\begin{array}{l}\text { Excellent- } 18-20 \\
\text { Good - 13-17 } \\
\text { Average - } 10-12 \\
\text { Fair - 7-9 } \\
\text { Poor- 5-6 } \\
\text { Very poor- } 0-5\end{array}$ \\
\hline Evaluation & $\begin{array}{l}\text { "To assess the credibility of } \\
\text { statements or other representations } \\
\text { that are accounts or descriptions of a } \\
\text { person's perception, experience, } \\
\text { situation, judgment, belief, or opinion; } \\
\text { and to assess the logical strength of } \\
\text { the actual or intended inferential } \\
\text { relationships among statements, } \\
\text { descriptions, questions, or other forms } \\
\text { of representation" }\end{array}$ & $\begin{array}{l}\text { Assess } \\
\text { credibility of } \\
\text { claims } \\
\text { Assess quality } \\
\text { of arguments } \\
\text { that were made } \\
\text { using } \\
\text { inductive or } \\
\text { deductive } \\
\text { reasoning }\end{array}$ & $\begin{array}{l}\text { Excellent-18-20 } \\
\text { Good - 13-17 } \\
\text { Average - } 10-12 \\
\text { Fair - 7-9 } \\
\text { Poor- 5-6 } \\
\text { Very poor- } 0-5\end{array}$ \\
\hline Explanation & $\begin{array}{l}\text { "To state and to justify that reasoning } \\
\text { in terms of the evidential, conceptual, } \\
\text { methodological, criteriological, and } \\
\text { contextual considerations upon which } \\
\text { one's results were based; and to } \\
\text { present one's reasoning in the form of } \\
\text { cogent arguments" }\end{array}$ & $\begin{array}{l}\text { State results } \\
\text { Justify } \\
\text { procedures } \\
\text { Present } \\
\text { arguments }\end{array}$ & $\begin{array}{l}\text { Excellent- } 9-10 \\
\text { Good - } 7-8 \\
\text { Average - 5-6 } \\
\text { Fair - 3-4 } \\
\text { Poor- } 1-2 \\
\text { Very poor/Fail- } \\
0\end{array}$ \\
\hline
\end{tabular}




\begin{tabular}{|c|c|c|c|}
\hline $\begin{array}{l}\text { Self- } \\
\text { Regulation }\end{array}$ & $\begin{array}{l}\text { "Self-consciously to monitor one's } \\
\text { cognitive activities, the elements used } \\
\text { in those activities, and the results } \\
\text { educed, particularly by applying skills } \\
\text { in analysis, and evaluation to one's } \\
\text { own inferential judgments with a view } \\
\text { toward questioning, confirming, } \\
\text { validating, or correcting either one's } \\
\text { reasoning or one's results" }\end{array}$ & $\begin{array}{l}\text { Self-monitor } \\
\text { Self-correct }\end{array}$ & $\begin{array}{l}\text { Excellent- 9-10 } \\
\text { Good - 7-8 } \\
\text { Average - 5-6 } \\
\text { Fair - 3-4 } \\
\text { Poor- } 1-2 \\
\text { Very poor/Fail- } \\
0\end{array}$ \\
\hline
\end{tabular}

Table 2. Critical Thinking category and its score

\begin{tabular}{lc}
\hline \multicolumn{1}{c}{ Category } & Score \\
\hline 1.Interpretation & 20 \\
\hline 2.Analysis & 20 \\
\hline 3.Inference & 20 \\
\hline 4.Evaluation & 20 \\
\hline 5.Explanation & 10 \\
\hline 6.Self-Regulation & 10 \\
\hline \multicolumn{1}{c}{ Total } & $\mathbf{1 0 0}$ \\
\hline
\end{tabular}

\section{Findings and discussion}

To cultivate students' critical thinking skills by using short-videos, the researcher used pair discussion forum in which the student work in a pair of two and keep giving and asking for opinions. Among the questions are; (1) what do you think about the video?, (2) why do you think that?, (3) what is your knowledge based upon the video?, (4) what does it implies and presuppose?, (5) what explains it, connects to it, leads from it?, (6) how are you viewing it?, (7) should it be viewed from different perspective?, and additional questions students could create by using (8) if, how about, and if you were-were. The students have a very limited answer and most of them cannot explain the reasons.

From those questions, the students, actually, are expected to perform the 4C skills: communicative.1) by responding to the questions (they will achieve communicative skill); collaborative. 2) by working in pairs (they will collaborate); critical thinking and problem-solving. 3 ) by thinking about the hidden part of the shown videos (they will think critically, and will try to solve the problem logically based on their own perspectives); and creative and innovative. 4) by relating the short-videos to their own life activities (they will improve their creativity and innovation to solve any kind of problem that might appear in their life activities).

After the researcher turned the video for one to four minutes with a pause in the middle or in the required minutes, the students have to guess what will happen or the students have to answer the related questions and explain it with good reason(s). Then after watching the whole part of the short video, they have to start thinking critically, evaluate the problem, and try to give logical answers for the questions by connecting the video to their real life.

\section{Students' critical thinking skills}

The researcher after implementing the short-videos with junior high school students she analyzed the collected data using Facione (2015) rubric which includes six objectives of critical thinking skills, interpretation, analysis, inference, evaluation, explanation, and self-regulation. The analyzed data didn't display good results. It can be clearly seen in the following table;

Table 3. Scoring critical thinking skills of students' based Facione (2015) cognitive skills

\begin{tabular}{cccccccc}
\hline No & Category & $\begin{array}{c}\text { Excellen } \\
\mathbf{t}(\mathbf{1 8 - 2 0})\end{array}$ & $\begin{array}{c}\text { Good } \\
(\mathbf{1 3 - 1 7})\end{array}$ & $\begin{array}{c}\text { Average } \\
(\mathbf{1 0 - 1 2})\end{array}$ & $\begin{array}{c}\text { Fair } \\
\mathbf{( 7 - 9 )}\end{array}$ & $\begin{array}{c}\text { Poor } \\
(\mathbf{5 - 6})\end{array}$ & $\begin{array}{c}\text { Very poor } \\
(\mathbf{0 - 5})\end{array}$ \\
\hline 1 & Interpretation & $0 \mathrm{st} / 130 \mathrm{st}$ & $4 \mathrm{st} / 130 \mathrm{st}$ & $10 \mathrm{st} / 130 \mathrm{st}$ & $102 \mathrm{st} / 130 \mathrm{st}$ & $12 \mathrm{st} / 130 \mathrm{st}$ & $4 \mathrm{st} / 130 \mathrm{st}$ \\
\hline 2 & Analysis & $2 \mathrm{st} / 130 \mathrm{st}$ & $2 \mathrm{st} / 130 \mathrm{st}$ & $78 \mathrm{st} / 130 \mathrm{st}$ & $32 \mathrm{st} / 130 \mathrm{st}$ & $12 \mathrm{st} / 130 \mathrm{st}$ & $4 \mathrm{st} / 130 \mathrm{st}$ \\
\hline 3 & Inference & $8 \mathrm{st} / 130 \mathrm{st}$ & $24 \mathrm{st} / 130 \mathrm{st}$ & $88 \mathrm{st} / 130 \mathrm{st}$ & $6 \mathrm{st} / 130 \mathrm{st}$ & $2 \mathrm{st} / 130 \mathrm{st}$ & $2 \mathrm{st} / 130 \mathrm{st}$ \\
\hline
\end{tabular}




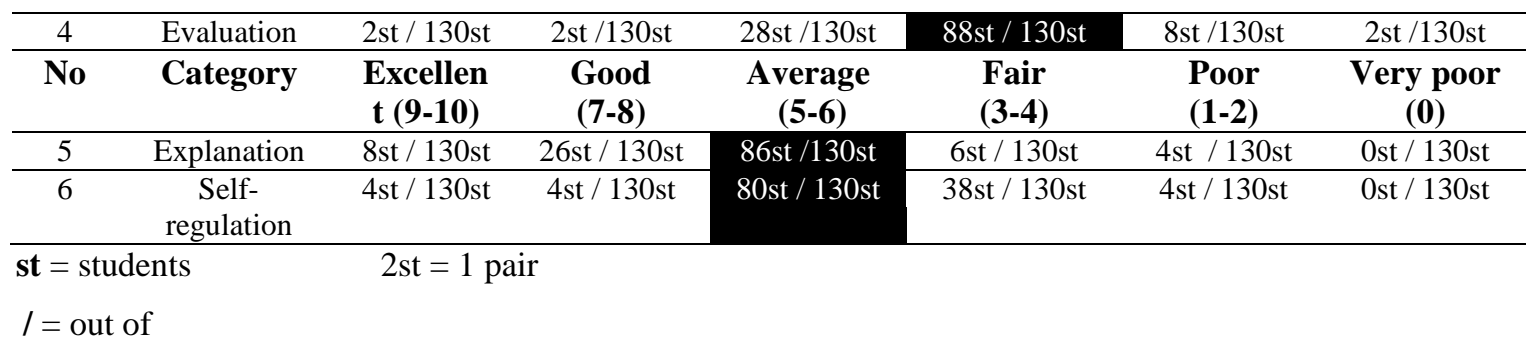

Since the researcher used the pair work in her teaching process, the data also obtained from pairs and the students' respond accepted directly based on two students' discussions. The results of their response show that they were still on average and fair levels. The majority of the students barely on in fair level performed the meaning, situations, data, events, judgments, conventions, beliefs, rules, or procedures, which are belong to the category of interpretation. Only 2 pairs from 5 classes (130 students) performed better than others. There were 5 pairs responded in average level, and the rest pairs almost couldn't respond anything or they performed poorly and very poorly.

The students while watching the videos they also asked to analyze by examining the ideas, identifying the arguments, and identifying the reasons and claims. However, they admit that they didn't understand the narrator's speech in the video and couldn't identify what was actually going in the video. As a result, the majority students' response only showed the average level of critical thinking.

The same problem happened when the students were doing the evaluation. They weren't really sure with their answers and were expecting the exact answers from the instructor. They made very weak conclusions. The students respond to what they see from the video but they still were far to do the logical evaluation. Only 2 pairs could give good examples. Those students linked the played video with their life experience and it was clear those 2 pairs had developed thinking even before this study. They had good logical reasons with examples and the answers were suitable to the questions.

The self-regulation also was at an average level since the students mostly were learning the language using digital translators and they weren't even aware that they were making mistakes while speaking in English. However, there were many students who used the phrases "I mean", "how to say", "how to explain". That self-monitor still was accepted at an average level. Only 2-3 pairs were clearly aware of their mistakes, for example, instead of saying "she says that" they said "she say that", "there is" instead of "there are", or "how many" instead of "how much". However, they ask for apologizing by saying "sorry" and directly corrected themselves using the correct tenses and words. There were students even didn't know the meaning of the words, and they made funny answers for the questions. Some answers were unclear unless they used their first language.

The next step that students needed to do were to explain, or after each short-video, they had to state results, justify procedures, and present arguments based on their point of view. Since they got some information while doing an evaluation, it wasn't that hard for them to do an explanation later on. However, the high number of students result still showed the average level of critical thinking skills. Despite the fact, while applying the explanation step, the researcher realized that the students more preferred memorizing the information than arguing with logical viewpoints.

The same results were obtained from students' inference skill. They couldn't make logically valid or justified conclusions. The same repetition appeared in their responses to the questions. The researcher also found that most students almost never asked questions. The reasons most probably the students were shy, or indeed didn't understand the topic, or they didn't have any interest in learning the English language, or they were afraid to make mistakes while asking questions. Nevertheless, they couldn't hide how happy they were when the classes become a competitive environment. Even though they couldn't debate with logical reasons, they still support their pairs to answer the questions well and accurate.

Overall results tell us that he students' critical thinking skills couldn't be improved significantly after having video treatment. Their critical thinking levels were still in fairly average categories. The students' critical thinking skills also presented in the form of percentages in the following chart; 


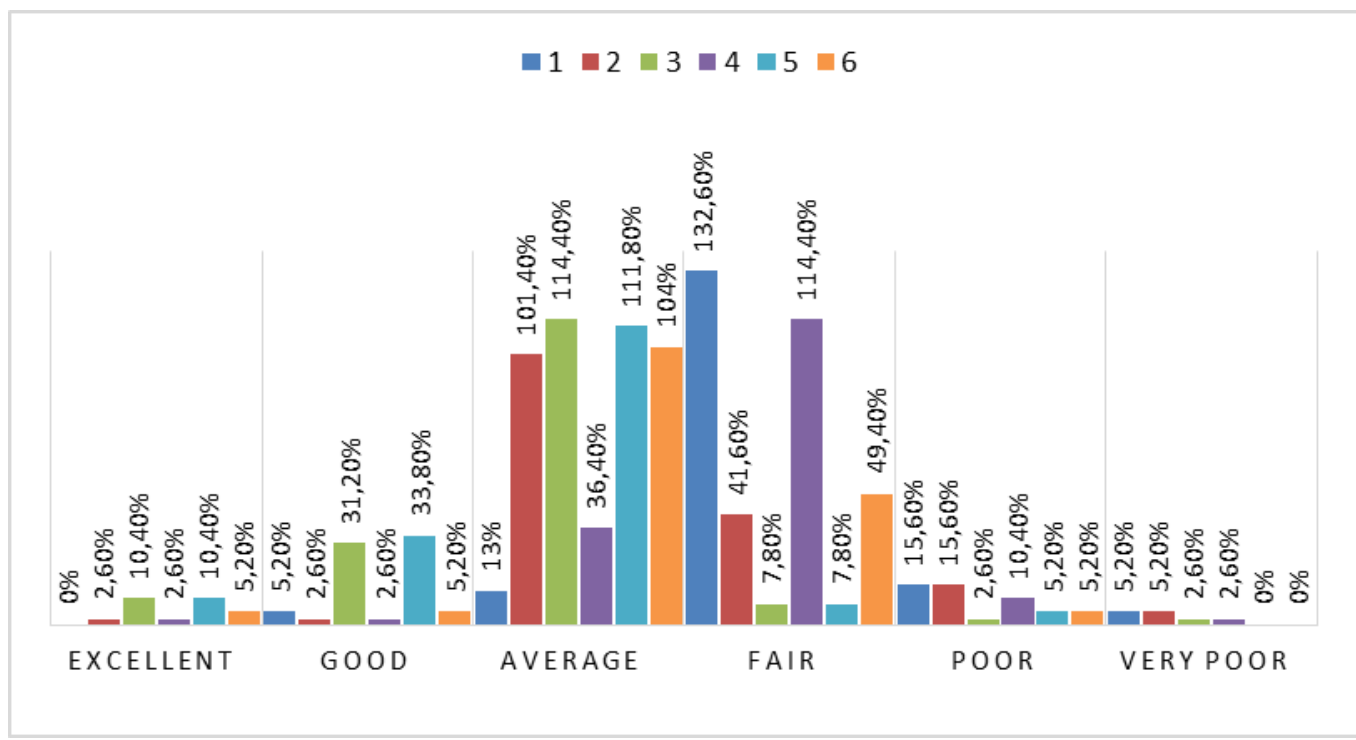

Fig. 1. The students' CT results in percentage

The findings are similar to the previous research which indicated a low level of students' critical thinking in EFL (Setyarini, 2019). Such low level to some extent can be affected by a lack of ideas, topic familiarity, lack of vocabularies to express the ideas, prior knowledge (Fadhillah, 2017 and Navaie, Saeedi \& Khatami, 2018), or classrooms tradition which rely heavily on instructor, or the transfer of information directly from teacher to student. As mentioned by Piker \& Foster (1996), those traditional ways of teaching, which involved repetition and memorization of previously taught materials did not lead the students to critical thinking.

In general, the results indicate the students' interpretation skills were fair with the score of 9 out of 20; analytical skill was 12; evaluation skill was 9 out of 20; self-regulation was in average criterion with the score of 5 out of 10 and in good level of explanatory's skill with the score 6 out of 10, while 12 for inferences (average level). It can be also seen in following graphic;

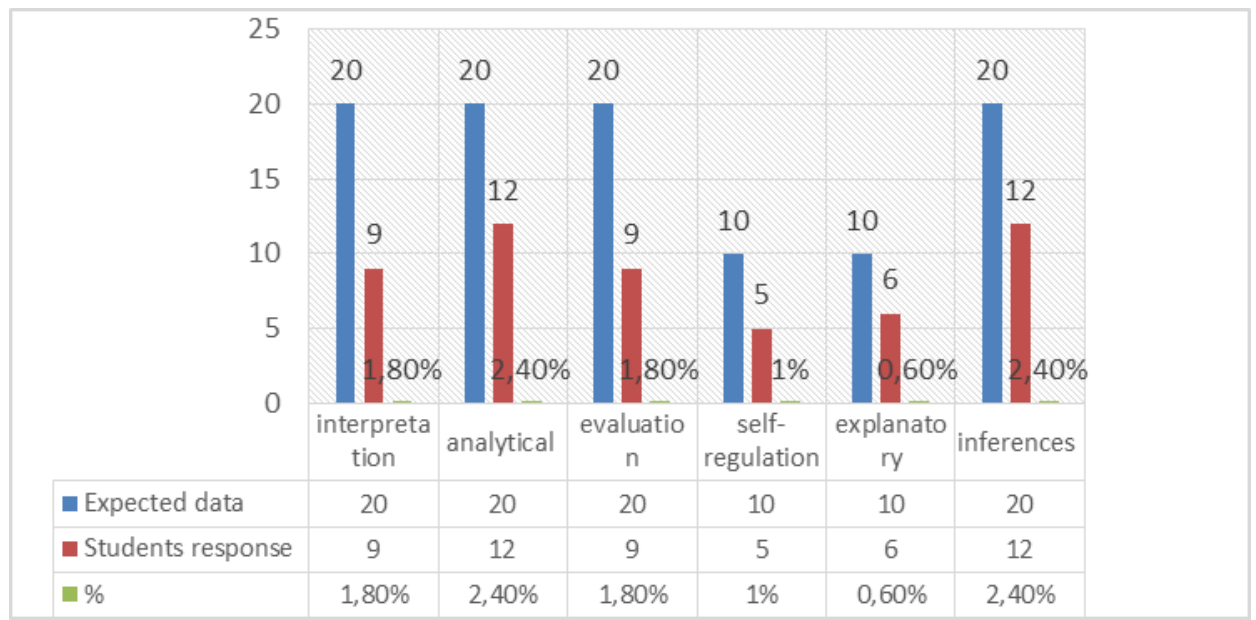

Fig. 2.130 Students' critical thinking skill results

The researcher does aware that in order to foster students' critical thinking, whole-class dialogue strategies shift the development of ideas to the student to create an opportunity for practice in analyzing and evaluating information. The teacher should begin the class discussion before students watch the video.

\section{Students' 4C (communicative, collaborative, critical and creative thinking) skills}

In order to cultivate students' critical thinking skills, integrating 4C skills and using technology in teaching and learning process might be real advantage (Dwyer, 2019). In this research the 
researcher integrated $4 \mathrm{C}$ skills practically. Since the study mainly focus on cultivating critical thinking skills to the students, the $4 \mathrm{C}$ skill information of the students she collected generally. The students' results presented in the following table;

Table 4. Students' 4C skills

\begin{tabular}{|c|c|c|c|c|c|c|}
\hline Objectives & 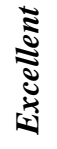 & $\begin{array}{l}\mathbb{8} \\
\mathbb{8}\end{array}$ & 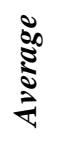 & $\stackrel{\Xi}{ \pm}$ & $\stackrel{\grave{d}}{2}$ & 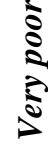 \\
\hline Communicative skills & & & $\sqrt{ }$ & & & \\
\hline Collaborative skills & $\sqrt{ }$ & & & & & \\
\hline Critical thinking and Problem solving skills & & & $\sqrt{ }$ & & & \\
\hline Creative and Innovative skills & & & $\sqrt{ }$ & & & \\
\hline
\end{tabular}

The table above presents the students' 4C ability in English subject. The results show that, majority of the students were in average level at communicative skills, critical thinking and problem solving skills, and creative and innovative skills. However, the students had excellent collaborative skills. They really support, assist, respect, love, listen and bring out the best of each other. They work, solve the problems, make decisions, and respond to the questions together with fellows. There wasn't any problem with their collaborative skills.

\section{Conclusion}

This descriptive study is aimed to cultivate learners' critical thinking skills especially by using short-videos. This research involved 130 Junior High School students (SMP Negeri 1 Sedayu, Yogyakarta) grade IX. The students were homogeny in term of age, economic, and social background as well as in English language score. Facione's critical thinking rubrics were used to point out the level of learners' critical thinking such as their interpretation, analysis, evaluation, inference, explanation, and self-regulation skill of short video. The researcher believed that using technology could help students to foster their critical-thinking skills. However, in this study the researcher came out with different results, she examined the students with several questions related to short-videos. The results of the students' showed that their critical thinking skills didn't improve significantly after having video treatment. Their critical thinking levels were still in fairly average categories. The average score of all item in pre-test critical thinking skills was at fair level with the score 9 out of 20. The results indicate the students' interpretation skills were fair with the score of 9 out of 20; analytical skill was 12; evaluation skill was 9 out of 20; self-regulation was in fair criterion with the score of 5 out of 10 and good level of explanatory's skill with the score 6 out of 10 , while 12 for inferences. It can be concluded that the critical thinking skill of the students of Junior High School was still unsatisfactory as most of them can only reach a fair level. The use of video cannot improve all critical thinking skills. Therefore, some more practices on critical thinking are needed.

\section{Acknowledgment}

The researcher would like to thank Head Master of SMP 1 Kemusuk, Argomulyo, Sedayu Yogyakarta for giving the chance to conduct research at his school.

\section{References}

Alharbi, H. A. (2015). Improving Students' English Speaking Proficiency in Saudi Public Schools. International Journal of Instruction, 8(1), 105-116.

Bransford, J. D., Brown, A. L., \& Cocking, R. R. (2000). How people learn (Vol. 11). Washington, DC: National academy press.

Brown, H. D. (1999). Some practical thoughts about student-sensitive critical pedagogy. 
LANGUAGE TEACHER-KYOTO-JALT-, 23, 15-16.

Pendidikan, B. S. N. (2010). Paradigma pendidikan nasional abad XXI. Jakarta: BSNP.

Caroselli, M. (2009). 50 Activities for Developing Critical Thinking Skill. HRD Press, Inc. Amherst. Massachusetts.

Carvajal, T., \& Paulina, S. (2019). The flipped classroom method in English speaking skill development (Master's thesis, Universidad Técnica de Ambato. Dirección de Posgrado. Maestria en la Enseñanza del Idioma Inglés como Lengua Extranjera).

Chou, M. H. (2017). Modelling the Relationship among Prior English Level, Self-efficacy, Critical Thinking, and Strategies in Reading Performance. The Journal, 1(1), 22.

Ding, A. C. E., Ottenbreit-Leftwich, A., Lu, Y. H., \& Glazewski, K. (2019). EFL Teachers' Pedagogical Beliefs and Practices With Regard to Using Technology. Journal of Digital Learning in Teacher Education, 1-20.

Djiwandono, P. I. (2013). Critical thinking skills for language students. TEFLIN Journal, 24(1), 3247.

Dwyer, W. (2019). Project Based Learning Course Integration for Elementary Science Methods.

Elisanti, E., Sajidan, S., \& Prayitno, B. A. (2017, August). The Profile of Critical Thinking Skill Students in XI Grade of Senior High School. In 1st Annual International Conference on Mathematics, Science, and Education (ICoMSE 2017). Atlantis Press.

Pratiwi, E. B. (2012). Improving the speaking skill of the tenth grade students at SMA Berbudi Yogyakarta by using videos in the academic year of 2011/2012. Yogyakarta: Yogyakkarta State University.

Facione, P. A. (2015). Critical Thinking: What It Is and Why It counts. Measured Reasons LLC, Hermosa Beach, CA. Journal.

Fadhillah, A. M. (2017). Embedding Critical Thinking Through Critical Reading: Teaching Narrative Text In Junior High School. Journal of English and Education, 5(2), 92-102.

Fahim, M., Bagherkazemi, M., \& Alemi, M. (2010). The relationship between test takers' critical thinking ability and their performance on the reading section of TOEFL. Journal of Language Teaching and Research, 1(6), 830.

Gurbangeldiyewna, A. M., \& Hermayawati, H. (2017). The Effectiveness Of English Interactive Media In Teaching Writing (An Experimental Study Conducted For Eleventh Graders In SMA N 1 Sedayu, Bantul Yogyakarta). JELE (Journal of English Language and Education), $3(1), 17-28$.

Haridza, R., \& Irving, K. E. (2017, February). Developing critical thinking of middle school students using problem based learning 4 core Areas (PBL4C) model. In Journal of Physics: Conference Series (Vol. 812, No. 1, p. 012081). IOP Publishing.

Harmer, J. (2001). The Practice of English Language Teaching. (3rd Ed.). London: Longman Group Ltd.

Hawks, S. J., Turner, K. M., Derouin, A. L., Hueckel, R. M., Leonardelli, A. K., \& Oermann, M. H. (2016, October). Writing across the curriculum: Strategies to improve the writing skills of nursing students. In Nursing forum (Vol. 51, No. 4, pp. 261-267).

Hidayat, R. N., Rukmini, D., \& Bharati, D. A. L. (2019). Developing Problem-Solving Based Assessment to Stimulate Critical Thinking and Creativity of Students' Writing Skill. English Education Journal, 9(2), 164-171. 
Ilyas, H. P. (2018). The Quest for Critical Thinking Framework in ELT. Celt: A Journal of Culture, English Language Teaching \& Literature, 18(2), 304-326.

Indah, R. N., \& Kusuma, A. W. (2016). Factors affecting the development of critical thinking of Indonesian learners of English language. Journal of Humanities And Social Science, 21(6), 86-94.

Indah, R. N. (2013). Topic familiarity, writing proficiency and critical thinking skills. Unpublished Dissertation. Malang: State University of Malang.

Kamali, Z., \& Fahim, M. (2011). The Relationship between Critical Thinking Ability of Iranian EFL Learners and Their Resilience Level Facing Unfamiliar Vocabulary Items in Reading. Journal of Language Teaching \& Research, 2(1).

Krathwohl, D. R., \& Anderson, L. W. (2009). A taxonomy for learning, teaching, and assessing: A revision of Bloom's taxonomy of educational objectives. Longman.

Lee, E., \& Hannafin, M. J. (2016). A design framework for enhancing engagement in studentcentered learning: Own it, learn it, and share it. Educational technology research and development, 64(4), 707-734.

Masduqi, H. (2011). Critical thinking skills and meaning in English language teaching. TEFLIN Journal, 22(2), 185-200.

McQuiggan, S., McQuiggan, J., Sabourin, J., \& Kosturko, L. (2015). Mobile learning: A handbook for developers, educators, and learners. John Wiley \& Sons.

Navaie, L. A., Saeedi, Z., \& Khatami, M. (2018). The Compatibility of Mindfulness and Critical Thinking among EFL Learners. The Journal of AsiaTEFL, 15(3), 811-818.

Ennis, R. H. (1996). Critical thinking dispositions: Their nature and assessability. Informal logic, $18(2)$.

Ohler, J. B. (2013). Digital storytelling in the classroom: New media pathways to literacy, learning, and creativity. Corwin Press.

Omar, A., \& Albakri, I. S. M. A. (2016). Thinking maps to promote critical thinking through the teaching of literature in the esl context. Indonesian Journal of English Language Teaching and Applied Linguistics, 1(1), 23-35.

Paul, R. (1995). Critical thinking: How to prepare students for a rapidly changing world. Foundation for Critical Thinking.

Pikkert, J. J., \& Foster, L. (1996). Critical thinking skills among third year Indonesian English students. RELC Journal, 27(2), 56-64.

Pinter, A. (2017). Teaching young language learners. Oxford University Press.

PISA. (2016). PISA 2015 result. (Online). Retrieved from: (http://www.keepeek.com/Digit alAssetManagement/oecd/education/pisa-2015-results-volume).

Richards, J. C., \& Renandya, W. A. (Eds.). (2002). Methodology in language teaching: An anthology of current practice. Cambridge university press.

Ruggiero, V. R., \& Ruggerio, V. R. (2004). The art of thinking: A guide to critical and creative thought. Pearson/Longman.

Rundell, M. (2002). Macmillan English Dictionary: The End of.

Salomon, S. Lowther, D. Russell, J. (2007). Instructional Technology and Media for Learning. 9th 
Ed. New Jersey: Pearson Education Inc.

Samanhudi, U., \& Sampurna, P. (2010). Researching students' critical thinking in EFL writing class (a case study in English education department, Untirta). TEFLIN 57th Revitalizing Professionalism in ELT as a Response to Globalized World. Bandung: Indonesia University of Education.

Saputri, A. C., \& Rinanto, Y. (2018, April). Critical thinking skills profile of senior high school students in Biology learning. In Journal of Physics: Conference Series (Vol. 1006, No. 1, p. 012002). IOP Publishing.

Setyarini, S. (2019, March). Higher Order Thinking Skills in Storytelling for Teaching English to Junior High School Students: A shortcut to fulfill learning objectives of 21st century. In Second Conference on Language, Literature, Education, and Culture (ICOLLITE 2018). Atlantis Press.

Shirkhani, S., \& Fahim, M. (2011). Enhancing critical thinking in foreign language learners. Procedia-Social and Behavioral Sciences, 29, 111-115.

Singh, R. K. V., \& Shaari, A. H. (2019). The analysis of Higher-Order Thinking skills in English reading comprehension tests in Malaysia. Geografia-Malaysian Journal of Society and Space, 15(1).

Sulla, N., Bosco, T., \& Marks, J. (2019). Students Taking Charge Implementation Guide for Leaders: Inside the Learner-Active, Technology-Infused Classroom. Routledge.

Yang, Y. T. C., \& Wu, W. C. I. (2012). Digital storytelling for enhancing student academic achievement, critical thinking, and learning motivation: A year-long experimental study. Computers \& education, 59(2), 339-352. 